GRASAS Y ACEITES 72 (3)

July-September 2021, e419

ISSN-L: 0017-3495

https://doi.org/10.3989/gya.0559201

\title{
Chemical parameters and antioxidant activity of turning color natural-style table olives of the Sigoise cultivar
}

\author{
$\oplus$ F. Ait Chabane ${ }^{\mathrm{a}}, \oplus \mathrm{A}$. Tamendjari ${ }^{\mathrm{a}}, \oplus \mathrm{P}$. Rovellini ${ }^{\mathrm{b}}, \oplus \mathrm{C}$. Romero $^{\mathrm{c}}$ and $\oplus \mathrm{E}$. Medina $^{\mathrm{c}, \otimes}$ \\ aLaboratoire de Biochimie Appliquée Faculté des sciences de la nature et de la vie - Université de Bejaia, 06000, Bejaia, Algeria. \\ bINNOVHUB - SSI Azienda Speciale della Camera di Commercio di Milano Area SSOG, Via Giuseppe Colombo 79, 20133, Milan, Italy. \\ 'Food Biotechnology Department, Instituto de la Grasa, IG-CSIC. Crta. Utrera km 1, Ed. 46, 41013, Seville, Spain. \\ ${ }^{\square}$ Corresponding author: emedina@ig.csic.es
}

Submitted: 19 May 2020; Accepted: 24 June 2020; Published online: 15 September 2021

SUMMARY: A chemical characterization of turning color table olives of the Sigoise variety was made through their processing as naturalstyle. Polyphenols, sugars, tocopherols, fatty acids, and antioxidant activity in the olives were monitored throughout the elaboration process. Oleuropein, salidroside, hydroxytyrosol 4-glucoside, rutin, ligustroside and verbascoside showed a decrease of 16.90-83.34\%, while hydroxytyrosol increased during the first months of brining. Glucose was consumed by $90 \%$ due to the metabolism of the fermentative microbiota. The tocopherol content remained stable during the process and only the $\alpha$-tocopherol decreased. The fatty acids were not affected. The loss in antioxidant compounds resulted in a decrease in the percentage of DPPH radical inhibition from $75.91 \%$ in the raw fruit to $44.20 \%$ after 150 days of brining. Therefore, the turning color natural table olives of the Sigoise variety are a good source of bioactive compounds.

KEYWORDS: Antioxidant activity; Polyphenols; Sigoise cultivar; Sugars; Tocopherols

RESUMEN: Parámetros químicos y actividad antioxidante de aceitunas de mesa al estilo natural de color cambiante de la variedad Sigoise. La caracterización química de las aceitunas en salmuera de color cambiante de la variedad Sigoise se ha estudiado durante el proceso de elaboración, en particular la concentración de fenoles, azúcares, tocoferoles, ácidos grasos y la actividad antioxidante. La concentración de oleuropeína, salidrósido, hidroxitirosol 4-glucósido, rutina, ligustrósido y verbascósido disminuyó un 16,90-83,34\% durante el primer mes en salmuera. El 90\% de la glucosa fue consumida debido al metabolismo de la microbiota fermentativa. El contenido en tocoferoles se mantuvo constante durante el proceso y solo disminuyó el $\alpha$-tocoferol. Los ácidos grasos no se vieron afectados. La pérdida de actividad antioxidante se tradujo en una disminución del porcentaje de inhibición del radical DPPH de un 75,91\% del fruto fresco a 44,20\% después de 150 días en salmuera. A pesar de todo, la aceituna color cambiante de la variedad Sigoise en salmuera es una buena fuente de compuestos bioactivos.

PALABRAS CLAVE: Actividad antioxidante; Azúcares; Polifenoles; Tocoferoles; Variedad Sigoise

Citation/Cómo citar este artículo: Ait Chabane F, Tamendjari A, Rovellini P, Romero C, Medina E. 2021. Chemical parameters and antioxidant activity of turning color natural-style table olives of Sigoise cultivar. Grasas Aceites 72 (3), e419. https://doi.org/10.3989/ gya.0559201

Copyright: $(2021$ CSIC. This is an open-access article distributed under the terms of the Creative Commons Attribution 4.0 International (CC BY 4.0) License. 


\section{INTRODUCTION}

Table olives are elaborated from the fruit of olive tree (Olea europaea L.) and they are considered the most popular fermented vegetable in the Mediterranean countries. The production of table olives in Algeria is estimated at 293000 tons (IOC, 2020) and represents $10 \%$ of worldwide production. Olives are mainly composed of water (60-75\%) and lipids (12-30\%). The fruits also contain a small amount of proteins (1$2 \%$ ) and sugars (2.6-6\%). However, this composition depends on several factors, such as the type of cultivar and the ripening stage (Boskou et al., 2014). Among the minor compounds, polyphenols are the most relevant and represent the $1-3 \%$ of the fresh pulp weight. Oleuropein is the major phenolic compound and is responsible for the bitter taste, which makes the fresh fruit inedible (Kiai and Hafidi, 2014).

There are three main types of preparations which are widely used worldwide to reduce the bitterness: Spanish-style olives, Californian-style olives and natural olives or Greek-style. The two first use a diluted sodium hydroxide solution to hydrolyze the molecule of the oleuropein into non-bitter compounds and the last process consists of directly brining without using any chemicals.

Recently, there has been a growing interest in the characterization of some bioactive compounds in table olives, in particular polyphenols and tocopherols, and their relationship with the antioxidant activity which acts as a potent radical scavenger against free radicals (Sagratini et al., 2013). The phenolic fraction in table olives can be influenced by many factors such as the olive cultivar (Medina et al., 2010), the degree of maturity (Sousa et al., 2014) and the de-bittering process applied (Ben Othman et al., 2009). Many studies have been carried out to assess the effect of the elaboration processes on these components (Bleve et al., 2015; Issaoui et al., 2011; Johnson et al., 2018; Romero et al., 2004a). The Greek-style elaboration process showed higher total phenolic compounds than the Spanish or Californian-style processes and hydroxytyrosol was the predominate compound in all three styles of commercial olives (Johnson et al., 2018). Greek-style processing alos better preserved the tocopherol content than the Spanish-style elaboration (Hassapidou et al., 1994).

Despite all these studies, only a few works have been focused on turning color table olives. Changes in the polyphenol content in the turning color Sigoise variety during naturally brined olive processing was studied (Mettouchi et al., 2016). It was found that turning color Manzanilla olives in brine showed more polyphenol concentration than those elaborated as Spanish-style (Romero et al., 2004b). The sugar and polyol compositions in natural olives at the cherry stage of ripening were studied (Marsilio et al., 2001), concluding that the determination of these components is important to optimize table olive processing.

According to the "Trade Standard Applying to Table Olives" (IOC, 2004), "natural olives could be "green olives, turning color or black olives placed directly in brine, where they undergo complete or partial fermentation, preserved or not by the addition of acidifying agents". The maturity of the fruit affects the phenolic concentration and may contribute to significant consequences concerning the technology and quality of table olives. The Sigoise variety, which is grown mainly in the north-west of Algeria (Sig region) is the most popular variety used in Algeria as fermented green olives (Kacem and Karem, 2006). In this work, the elaboration of turning color table olives of the Sigoise cv. according to the natural process was studied to characterize the chemical composition and evaluate changes in polyphenols, sugars, tocopherols, fatty acids and antioxidant activity.

\section{MATERIALS AND METHODS}

\subsection{Processing and sampling}

Olives of the Algerian Sigoise variety (average weight $3.5 \mathrm{~g}$ ) were harvested at the turning color stage during the 2015-2016 season and placed in plastic tanks (30 L capacity). The olives were processed according to the natural style elaboration. An initial brine of $11 \% \mathrm{NaCl}$ was used to cover the fruits, which were then left at ambient temperature to follow spontaneous fermentation for five months. Samples were withdrawn periodically at 60,120 and 150 days of brining until the brine reached a $\mathrm{pH}$ of 4.3. Fresh fruits were also collected at the time of harvesting. Samples were stored frozen at $-20{ }^{\circ} \mathrm{C}$ until analysis.

\subsection{Determination of physical properties, moisture and oil content in fruits}

Fifteen olives from each sample were weighed. Length and diameter were measured using a digital calliper (150 mm (6")) (Stainless Hardened). The 
flesh/stone ratio was estimated to characterize the shape and size of the olives. The $\mathrm{pH}$ of the brines was monitored during the elaboration process with a $\mathrm{pH}$ meter (Crison Basic 20).

Fruit moisture was determined (Tovar et al., 2002). Five grams of fresh pulp were desiccated at $105^{\circ} \mathrm{C}$ until constant e weight.

Oil was extracted from dried olives with hexane in a Soxhlet apparatus for $6 \mathrm{~h}$ at $45^{\circ} \mathrm{C}$ (ECC) No $2568 / 91$ of July (1991). The solvent was removed by a rotary evaporator, and the oil was weighed and stored at $4{ }^{\circ} \mathrm{C}$ until further analysis. The results were expressed as percentage of dry weight.

\subsection{HPLC analysis of phenolic compounds}

The phenolic compounds were extracted from the olive pulp with dimethylsulfoxide (DMSO) as described by Susamci et al. (2017). $1.5 \mathrm{~g}$ of freezedried olive pulp were homogenized with $30 \mathrm{~mL}$ of DMSO and centrifuged at $6000 \mathrm{~g}$ after $30 \mathrm{~min}$ of contact. Then, an aliquot of $0.25 \mathrm{~mL}$ of supernatant was mixed with $0.5 \mathrm{~mL}$ of DMSO and $0.25 \mathrm{~mL}$ of $0.2 \mathrm{mM}$ syringic acid in DMSO (internal standard). The mixture was filtered through a $0.22 \mu \mathrm{m}$ pore size nylon filter, and an aliquot of $20 \mu \mathrm{L}$ was injected into the chromatograph. The analytical column, mobile phases, gradient and equipment were the same as those used by Susamci et al. (2017). The wavelengths selected for phenolic compounds were $280 \mathrm{~nm}$.

\subsection{HPLC analysis of sugars}

The sugars were extracted from the olive pulp as described elsewhere (Medina et al., 2007) with some modifications. One gram of freeze-dried olive flesh was mixed with $20 \mathrm{~mL}$ of boiling water and $2 \mathrm{~mL}$ of sorbitol $(7.5 \%, \mathrm{w} / \mathrm{v})$ as internal standard, vortexed for $1 \mathrm{~min}$ and kept in an ultrasonic bath for $3 \mathrm{~min}$. The mixture was centrifuged at $9000 \mathrm{~g}$ for 5 min and filtered through filter paper under vacuum into a $50 \mathrm{~mL}$ flask. A second extraction was repeated with another $20 \mathrm{~mL}$ of hot water and made up to volume. $2 \mathrm{~mL}$ of the filtered solution $(0.22 \mu \mathrm{m}$ pore size nylon filter) were put into contact with $1 \mathrm{~g}$ of the acidic resin Amberlite IR-120 plus $1 \mathrm{~g}$ of the basic resin Amberlite IRA-93, shaken for $30 \mathrm{~min}$, and centrifuged at $9000 \mathrm{~g}$ for $3 \mathrm{~min}$. An aliquot of $20 \mu \mathrm{L}$ was injected into the chromatograph. The analytical column, mobile phases, gradient and equipment were the same as those used by Medina et al. (2007).

\subsection{HPLC analysis of tocopherols}

After cold extraction of the oil in a laboratory mill (Levi-Dilon-Lerogsame), the tocopherol composition was evaluated using an HPLC system, analytical column, mobile phases, gradient and equipment as described by Rovellini et al. (1997). The wavelengths selected for tocopherols were 292 $\mathrm{nm}$. The different isomeric forms were identified by comparing other vegetable oils with typical tocopherol content distribution. The quantification was conducted using an external calibration solution of alpha-tocopherol in acetone $(0.01 \mathrm{mg} / \mathrm{mL})$.

\subsection{Fatty acid composition}

The fatty acid methyl esters (FAME) were prepared in a solution of $2 \mathrm{~N}$ methanolic potassium hydroxide according to the method described (Commission Delegated Regulation (EU) 2016/2095 of 26 September 2016 amending Regulation (EEC) No 2568/91) and analyzed by gas chromatography. An Agilent 7890 gas chromatograph (Agilent, Germany) equipped with capillary column HP88 (Agilent, Germany) $112-88177(100 \mathrm{~m}, 0.25 \mathrm{~mm}, 0.20 \mu \mathrm{m})$, a flame ionization detector (FID) and a split/splitless injector was used. The oven temperature was programmed as follows: from $60^{\circ} \mathrm{C}(1 \mathrm{~min})$ to 165 ${ }^{\circ} \mathrm{C}$ to $10{ }^{\circ} \mathrm{C} / \mathrm{min}$ and held for $1 \mathrm{~min}$; then heated to 225 at $2{ }^{\circ} \mathrm{C} / \mathrm{min}$ and finally an isothermal was used for $25 \mathrm{~min}$. Helium was used as carrier gas.

\subsection{Antioxidant activity}

\subsubsection{Radical scavenging activity of methanolic extracts against DPPH radical}

The extraction of phenolic compounds from the pulp was performed according to the method described by McDonald et al. (2001). Ten grams of dried pulp were mixed with $50 \mathrm{~mL}$ of methanol/ water $(80: 20, \mathrm{v} / \mathrm{v})$ for 20 minutes. The mixture was centrifuged at $3000 \mathrm{rpm}$ for 5 minutes. Then, the residue was extracted twice, and supernatants were combined and washed with hexane to eliminate the oil. The extract was filtered through a $0.45 \mu \mathrm{m}$ pore size filter. An aliquot of $0.5 \mathrm{~mL}$ of methanolic extracts was reacted with $3.9 \mathrm{~mL}$ of a methanolic solution of DPPH radical $(0.1 \mathrm{mM})$. The mixture was incubated for $30 \mathrm{~min}$ in the dark, and the 
absorbance was measured at $515 \mathrm{~nm}$. The radical inhibition was calculated according to the following formula:

$\%$ inhibition $=[$ (absorbance of control absorbance of the sample)/absorbance of control] x100 (Boskou et al., 2006).

The antiradical activity was expressed in $\mathrm{mg}$ of gallic acid equivalents (GAE)/100g of dry weight (DW). The EC50 value, which represents the concentration of sample required to inhibit $50 \%$ 2,2-diphenyl-1-picrylhydrazyl (DPPH) radical was determined for each extract.

\subsubsection{Reducing power}

The determination of reducing power was carried out (Zhan et al., 2006). An aliquot of 2.5 $\mathrm{mL}$ of the methanolic extract was mixed with 2.5 $\mathrm{mL}$ of phosphate buffer $(0.2 \mathrm{M}, \mathrm{pH} 6.6)$ and 2.5 $\mathrm{mL}$ of potassium ferricyanide $(1 \%)$. The mixture was incubated at $50{ }^{\circ} \mathrm{C}$ for $20 \mathrm{~min}$. Then, $2.5 \mathrm{ml}$ of trichloroacetic acid $(10 \%)$ were added, and the mixture was centrifuged at $3650 \mathrm{rpm}$ for $10 \mathrm{~min}$. $5 \mathrm{~mL}$ of supernatant were mixed with the same volume of distilled water, and $1 \mathrm{~mL}$ of ferric chloride $(0.1 \%)$ and the absorbance was measured at $700 \mathrm{~nm}$. The results were expressed as $\mathrm{mg}$ of quercetin equivalents $(\mathrm{QE}) / 100 \mathrm{~g}$ DW.

\subsection{Statistical analysis}

Three tests were performed and expressed as mean values $(n=3)$ for each analysis. Statistica software 10.0 (StatSoft, Inc., Tulsa, OK, USA) was used for data analysis. Statistical comparisons of the mean values for each experiment were performed by the least significant difference Newman-Keuls test and significance was defined at $\mathrm{p}<0.05$.

\section{RESULTS AND DISCUSSION}

\subsection{Physical characteristics, moisture and oil content}

Table 1 summarizes the main characteristics of olive drupes. The flesh-to-pit ratio is vital to evaluate the mass distribution between the flesh and the stone (Sakouhi et al., 2008). A proper appreciation requires drupe with flesh/pit equal to 5 (Rallo et al., 2018). Turning color olives of the Sigoise cultivar with a weight of $3.47 \mathrm{~g}$ and a flesh/stone ratio of about 5.09 can be considered appropriate for table olive processing. The olives have an oval shape, and the length/diameter ratio is greater than 1 .

The evolution of the $\mathrm{pH}$ of the brines during the fermentation of table olives showed a significant decrease from 6.65 initially to 4.2 after 150 days. A critical drop was noticed after 60 days of fermentation. This trend is due to the conversion of carbohydrates into organic acids, mainly by LAB metabolism. Also, the hydrolysis of oleuropein, which is decomposed by endogenous and bacterial enzymes in sugars and simple phenols, such as elenolic acid, may contribute to the drop in $\mathrm{pH}$ (Kiai and Hafidi, 2014).

The humidity varied between 52.74 and $54.70 \%$; whereas oil content varied between 42.98 and $44.61 \%$. Sigoise turning color table olives recorded a higher rate of oil compared to those reported for the Tunisian table olives (Meski) elaborated according to natural style (Issaoui et al., 2011). There was a non-significant effect of processing on all the main characteristics of table olives except for $\mathrm{pH}$.

TABLE 1. Physicochemical parameters in turning color table olives of the Sigoise variety during natural-style processing.

\begin{tabular}{|c|c|c|c|c|c|c|}
\hline $\begin{array}{c}\text { Time } \\
\text { (days) }\end{array}$ & Weight (g) & $\begin{array}{l}\text { Flesh to pit } \\
\text { ratio }\end{array}$ & $\begin{array}{l}\text { Length/diame- } \\
\text { ter ratio }\end{array}$ & pH & $\begin{array}{c}\text { Moisture con- } \\
\text { tent }(\%)\end{array}$ & $\begin{array}{c}\text { Oil content (\% } \\
\text { Dry weight) }\end{array}$ \\
\hline 0 & $3.49 \pm 0.49$ & $5.02 \pm 0.22$ & $1.32 \pm 0.06$ & $6.65 \pm 0.05 \mathrm{a}$ & $55.86 \pm 0.53$ & $44.61 \pm 1.45$ \\
\hline 60 & $3.51 \pm 0.74$ & $5.05 \pm 0.19$ & $1.34 \pm 0.06$ & $5.25 \pm 0.05 b$ & $52.75 \pm 0.67$ & $42.98 \pm 2.19$ \\
\hline 120 & $3.53 \pm 0.63$ & $5.01 \pm 0.13$ & $1.34 \pm 0.1$ & $4.45 \pm 0.05 c$ & $54.69 \pm 0.33$ & $44.34 \pm 1.18$ \\
\hline 150 & $3.47 \pm 0.34$ & $5.09 \pm 0.35$ & $1.35 \pm 0.07$ & $4.20 \pm 0.05 d$ & $53.72 \pm 0.04$ & $43.86 \pm 1.33$ \\
\hline
\end{tabular}

Results are given as mean \pm standard deviation of triplicate analyses. No significant differences were found among samples except for the $\mathrm{pH}$, which are indicated by different superscript letters using the Newman-Keuls test $(\mathrm{p}<0.05)$. 


\subsection{Phenolic compounds}

Polyphenols are considered to be the most antioxidant substrates in table olives. Still, some of them, in particular the oleuropein, confer a bitter taste which is not accepted by consumers and their removal is necessary (Boskou et al., 2006). The phenolic composition in the olives was studied in the raw fruit and throughout processing (Table 2). Hydroxytyrosol 4-glucoside and oleuropein were identified as the major polyphenols in the raw olive fruit with a concentration of 31867.9 and 27730.3 $\mathrm{mg} / \mathrm{kg} \mathrm{DW}$, respectively, followed by verbascoside, rutin, hydroxytyrosol, ligustroside and salidroside in minor concentrations. These results are in accordance with those found previously (Romero et al., 2004b).

Noticeable decreases in oleuropein, hydroxytyrosol 4-glucoside, rutin and ligustroside were observed after 150 days of brining, reaching concentrations of 10891.7, 10860.0, 310.1 and $252.1 \mathrm{mg} / \mathrm{kg} \mathrm{DW}$, respectively. Conversely, hydroxytyrosol and salidroside increased after 60 days and decreased at the end of processing to 1617.8 and $303.8 \mathrm{mg} / \mathrm{kg}$ respectively. Comselogoside did not show significant differences during processing. The same trend was observed by Sousa et al. (2014) which showed a decrease in oleuropein and increase in hydroxytyrosol in samples harvested at different stages of maturation. Moreover, several authors indicated that table olives processed according to the natural style underwent a significant decrease in oleuropein, which is followed by an increase in hydroxytyrosol as the main hydrolysis product during the first days of brining (Issaoui et al., 2011; Johnson et al., 2018; Ramirez et al., 2016).

The total polyphenol content in fresh olives was initially $67335.4 \mathrm{mg} / \mathrm{kg}$. This amount was significantly reduced during processing, reaching $26585.5 \mathrm{mg} / \mathrm{kg}$ after 150 days of brining, which corresponds to a decline in total polyphenols of $60.52 \%$ (Table 2). Similar total polyphenol concentrations for the Picholine variety in both raw and processed fruit were found (Issaoui et al., 2011). Likewise, Sigoise cv. showed a higher content in phenolic compounds compared to Meski and Manzanilla cultivars. The study conducted by Johnson et al. (2018) on levels of phenolic compounds in Spanish-style green (SP),

TABLE 2. Concentration ( $\mathrm{mg} / \mathrm{kg}$ of dry weight) of the phenolic compounds in turning color table olives of the Sigoise variety during natural-style processing.

Time (days)

\begin{tabular}{|c|c|c|c|c|}
\hline & $\mathbf{0}$ & 60 & 120 & 150 \\
\hline Hydroxytyrosol & $1291.8 \pm 84.1^{\mathrm{b}}$ & $2456.9 \pm 178.9^{\mathrm{a}}$ & $1679.6 \pm 95.8^{b}$ & $1617.8 \pm 152.2^{\mathrm{b}}$ \\
\hline Hydroxytyrosol 4-glucoside & $31867.9 \pm 1595.4^{\mathrm{a}}$ & $28753.7 \pm 748.5^{\mathrm{b}}$ & $16415.4 \pm 99.0^{c}$ & $10860.0 \pm 867.2^{\mathrm{d}}$ \\
\hline Salidroside & $684.3 \pm 22.7^{b}$ & $916.8 \pm 3.0^{\mathrm{a}}$ & $429.3 \pm 40.8^{c}$ & $303.8 \pm 25.1^{\mathrm{d}}$ \\
\hline Verbascoside & $2812.9 \pm 170.0^{\mathrm{a}}$ & $3854.6 \pm 117.8^{a}$ & $1952.9 \pm 126.0^{\mathrm{c}}$ & $2337.5 \pm 168.6^{\mathrm{b}}$ \\
\hline Oleuropein & $27730.3 \pm 702.9^{a}$ & $21128.2 \pm 655.1^{b}$ & $14049.0 \pm 526.5^{\mathrm{c}}$ & $10891.7 \pm 580.2^{\mathrm{d}}$ \\
\hline Comselogoside & $20.6 \pm 9.5^{\text {a }}$ & $17.2 \pm 4.0^{\mathrm{a}}$ & $19.8 \pm 4.8^{\mathrm{a}}$ & $12.3 \pm 8.3^{\text {a }}$ \\
\hline Rutin & $1861.1 \pm 82.1^{\mathrm{a}}$ & $771.2 \pm 69.1^{\mathrm{a}}$ & $389.3 \pm 60.9^{c}$ & $310.1 \pm 60.4^{\mathrm{c}}$ \\
\hline Ligustroside & $1066.5 \pm 126.4^{\mathrm{a}}$ & $531.4 \pm 20.3^{b}$ & $402.6 \pm 17.4^{\mathrm{c}}$ & $252.1 \pm 35.5^{\mathrm{d}}$ \\
\hline Sum of polyphenols & $67335.4 \pm 2233.4^{\text {a }}$ & $58430.2 \pm 1082.1^{b}$ & $35338.6 \pm 765.5^{\mathrm{c}}$ & $26585.5 \pm 1106.0^{d}$ \\
\hline
\end{tabular}

Results are given as mean \pm standard deviation of triplicate analyses. Significant differences in the same row are marked with different superscript letters using the Newman-Keuls test $(\mathrm{p}<0.05)$. 
Californian-style black ripe (CA), and Greek-style natural fermentation, showed that olives in brine had the highest concentrations; whereas CA olives had the lowest level.

It is well-known that the diffusion of polyphenols between fruits and the water phase takes place when olives are directly brined and soluble components move from olive to the surrounding solution (Poiana and Romeo, 2006). This diffusion can occur more rapidly if the cellular structure of the fruit becomes naturally soft. It was reported that the de-bittering process occurs by the breakdown of the oleuropein into non-bitter products by the action of the activity of endogenous enzymes, esterase and $\beta$-glucosidase during the first month of brining followed by slow chemical hydrolysis throughout the rest of the storage (Ramirez et al., 2016). The acidic conditions of the brine can also favor the chemical hydrolysis of oleuropein (Medina et al., 2008). Also, an oleuropeinolytic activity has been reported for different yeast and lactic acid bacteria strains, which are responsible for fermentation in natural table olives (Bonatsou et al., 2015; Ramírez et al., 2017).

\subsection{Sugars}

The sugar content in olives is the most important fermentative substrate for the growth of the microorganisms which are responsible for fermentation during the natural style elaboration. The soluble sugars are transformed by microorganisms into organic acids as the product of the fermentation and second metabolites responsible for the desirable organoleptic characteristics in the final product. As shown in Figure 1 , the main sugars in the raw olive fruits are glucose, mannitol, fructose and sucrose with concentrations of $29.2,10.5,5.2$ and $1.5 \mathrm{~g} / \mathrm{kg}$, respectively. The sugar content registered a significant decrease after 150 days of brining with a glucose degradation rate of $91.05 \%$ and lower for the mannitol and fructose (74.57 and $74.76 \%$, respectively). Sucrose was consumed in the first 60 days of brining. A decrease in sugar content has also been noted for different cultivars elaborated in the natural style (Bianchi, 2003; Issaoui et al., 2011). Likewise, these results are in agreement with those noted (Bleve et al., 2015) for Taggiasca natural table olives but with a higher degradation rate for fructose $(92.28 \%)$ than for glucose $(83.55 \%)$.

\subsection{Tocopherols}

The study on tocopherols contributes to empowering the nutritional value and the biological properties like the antioxidant capacity of table olives (Sakouhi et al., 2008). The main tocopherol present in the oil fraction of raw olives was $\alpha$-tocopherol with $133.8 \mathrm{mg} / \mathrm{kg}$. $\beta, \gamma$, and $\delta$-tocopherol were present at in small amounts of $0.4,4.2$, and $1.5 \mathrm{mg} / \mathrm{kg}$, respectively (Table 3). A significant decrease was observed for $\alpha$-tocopherol throughout processing and a loss of

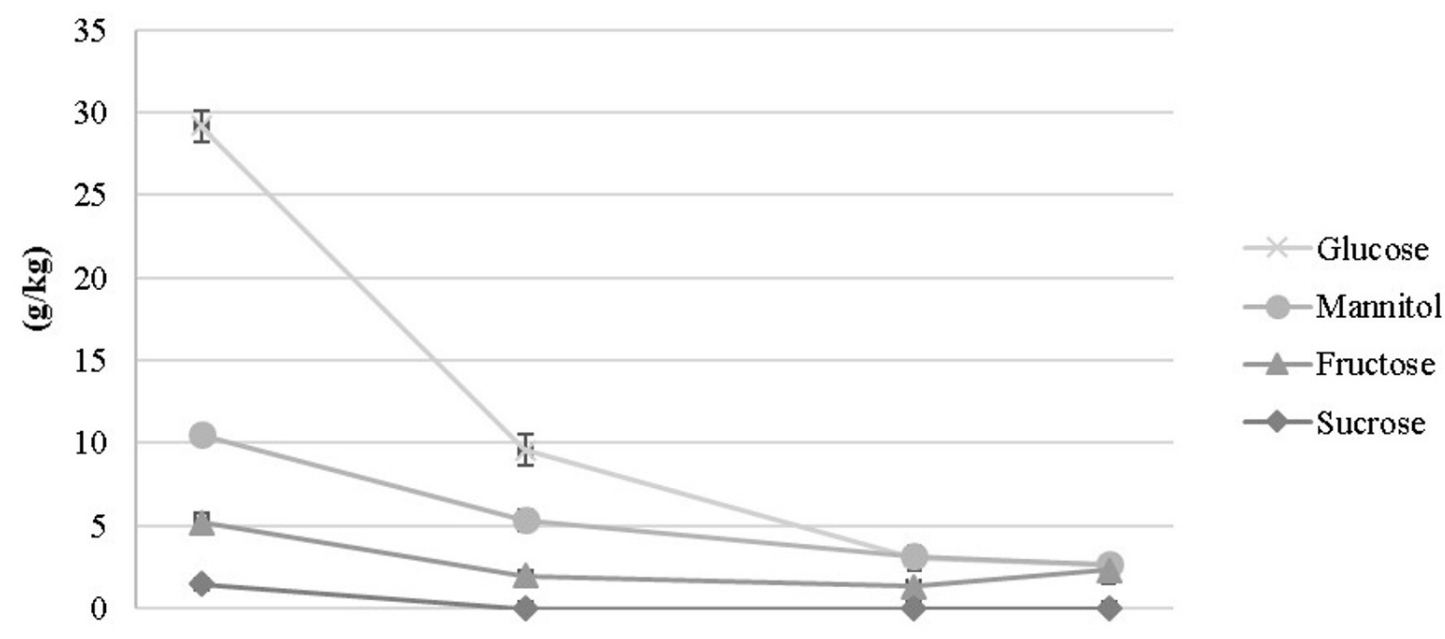

Time (Days)

FIGURE 1. Concentration of sugars $(\mathrm{g} / \mathrm{kg})$ in turning color table olive pulp of the Sigoise variety during natural-style processing. Results are given as the mean of triplicate analyses. Bars indicate standard deviation. 
TABLE 3. Concentration of tocopherols ( $\mathrm{mg} / \mathrm{kg}$ ) and fatty acids (\%) in turning color table olives of the Sigoise variety during natural-style processing.

\begin{tabular}{|c|c|c|c|c|}
\hline & \multicolumn{4}{|c|}{ Time (days) } \\
\hline & $\mathbf{0}$ & 60 & 120 & 150 \\
\hline$\alpha$-tocopherol & $133.8 \pm 3.9^{\mathrm{a}}$ & $131.8 \pm 3.5^{\mathrm{ab}}$ & $122.8 \pm 0.5^{\mathrm{b}}$ & $122.4 \pm 0.6^{\mathrm{b}}$ \\
\hline$\beta$-tocopherol & $1.5 \pm 0.1^{\mathrm{a}}$ & $1.5 \pm 0.1^{\mathrm{a}}$ & $1.4 \pm 0.1^{\mathrm{a}}$ & $1.4 \pm 0.1^{\mathrm{a}}$ \\
\hline$\gamma$-tocopherol & $4.2 \pm 0.4^{\mathrm{a}}$ & $4.3 \pm 0.4^{\mathrm{a}}$ & $4.5 \pm 0.2^{\mathrm{a}}$ & $4.5 \pm 0.1^{\mathrm{a}}$ \\
\hline$\delta$-tocopherol & $0.4 \pm 0.0^{\mathrm{a}}$ & $0.5 \pm 0.1^{\mathrm{a}}$ & $0.3 \pm 0.0^{\mathrm{a}}$ & $0.4 \pm 0.1^{\mathrm{a}}$ \\
\hline Sum of tocopherols & $139.8 \pm 4.5^{\mathrm{a}}$ & $138.1 \pm 3.7^{\mathrm{a}}$ & $128.9 \pm 0.4^{\mathrm{b}}$ & $128.8 \pm 0.7^{\mathrm{b}}$ \\
\hline C14:0 & $0.02 \pm 0.00$ & $0.02 \pm 0.00$ & $0.02 \pm 0.00$ & $0.02 \pm 0.00$ \\
\hline C16:0 & $9.09 \pm 0.04$ & $9.16 \pm 0.02$ & $9.12 \pm 0.01$ & $9.30 \pm 0.20$ \\
\hline C16:1 & $0.64 \pm 0.00$ & $0.64 \pm 0.01$ & $0.64 \pm 0.00$ & $0.66 \pm 0.02$ \\
\hline $\mathrm{C} 17: 0$ & $0.05 \pm 0.00$ & $0.05 \pm 0.00$ & $0.05 \pm 0.01$ & $0.06 \pm 0.00$ \\
\hline $\mathrm{C} 17: 1$ & $0.07 \pm 0.00$ & $0.07 \pm 0.00$ & $0.07 \pm 0.00$ & $0.08 \pm 0.00$ \\
\hline C18:0 & $2.84 \pm 0.00$ & $2.87 \pm 0.03$ & $2.84 \pm 0.02$ & $2.87 \pm 0.01$ \\
\hline C18:1 & $75.90 \pm 0.04$ & $75.72 \pm 0.04$ & $75.94 \pm 0.03$ & $75.67 \pm 0.18$ \\
\hline $\mathrm{C} 18: 2$ & $9.89 \pm 0.04$ & $9.98 \pm 0.03$ & $9.86 \pm 0.04$ & $9.86 \pm 0.04$ \\
\hline C18:3 & $0.75 \pm 0.00$ & $0.76 \pm 0.00$ & $0.75 \pm 0.00$ & $0.76 \pm 0.00$ \\
\hline C20:0 & $0.32 \pm 0.01$ & $0.32 \pm 0.00$ & $0.31 \pm 0.01$ & $0.31 \pm 0.01$ \\
\hline C20:1 & $0.33 \pm 0.00$ & $0.33 \pm 0.00$ & $0.32 \pm 0.00$ & $0.32 \pm 0.01$ \\
\hline $\mathrm{C} 22: 0$ & $0.07 \pm 0.00$ & $0.07 \pm 0.00$ & $0.07 \pm 0.01$ & $0.07 \pm 0.01$ \\
\hline $\mathrm{C} 24: 0$ & $003 \pm 0.00$ & $0.03 \pm 0.00$ & $0.03 \pm 0.00$ & $0.04 \pm 0.01$ \\
\hline trans $\mathrm{C} 18: 1$ & $0.02 \pm 0.01$ & $0.01 \pm 0.00$ & $0.02 \pm 0.01$ & $0.02 \pm 0.01$ \\
\hline trans $\mathrm{C} 18: 2$ & $0.00 \pm 0.00$ & $0.00 \pm 0.00$ & $0.00 \pm 0.00$ & $0.00 \pm 0.00$ \\
\hline trans $\mathrm{C} 18: 3$ & $0.00 \pm 0.00$ & $0.00 \pm 0.00$ & $0.00 \pm 0.00$ & $0.00 \pm 0.00$ \\
\hline Sum of trans & $0.02 \pm 0.01$ & $0.01 \pm 0.00$ & $0.02 \pm 0.01$ & $0.02 \pm 0.01$ \\
\hline
\end{tabular}

Results are given as mean \pm standard deviation. Significant differences in the same row are marked with different superscript letters ( $\mathrm{p}<$ $0.05)$. No significant differences were found for fatty acids among samples using the Newman-Keuls test ( $p<0.05)$. ND means not detected.

$7.88 \%$ was recorded after 150 days of brining, while the other isomers did not show significant changes.

The turning-color table olives of the Sigoise cv. registered higher tocopherol content than those found for Italian varieties (Sagratini et al., 2013) with maximum concentrations of $90 \mathrm{mg} /$ $\mathrm{kg}$ in several samples of table olives elaborated by different processing methods. Similarly, Sakouhi et al. (2008) recorded higher tocopherol levels in three cultivars (Meski, Sayali and Picholine) at a cherry stage of ripeness than green ones, but still lower than the Sigoise variety. Hassapidou et al. (1994) reported that the natural-style elaboration did not affect the $\alpha$-tocopherol contents in Conservolea or Kalamata black olives; however, the lye treatment used in the Spanish-style processing caused a reduction in $\alpha$-tocopherols (Boskou et al., 2014).

\subsection{Fatty acids}

The fatty acid composition (Table 3 ) showed that oleic acid (C18:1) was the major fatty acid in the olive flesh (75.90\% of the total). Linoleic (C18:2) and palmitic (C16:0) acids were present in similar amounts 
of 9.89 and $9.09 \%$, respectively. The variations related to processing were insignificant, which is in agreement with the results of many authors (Issaoui et al., 2011; Sakouhi et al., 2008). The stability of the fatty acids in processed olives could be related to their nature and the protective action of antioxidants. Oleic acid and tocopherols were present in considerable amounts in our variety. The trans forms of linoleic and linolenic acids were not detected, whereas trans-oleic acid (C18:1t) had a value $(0.02 \%)$ which was below the limit values requested by the Commission Regulation (EU); $\leq 0.05$ (Commission Delegated Regulation (EU) 2016/2095 of 26 September 2016 amending Regulation (EEC) No 2568/91). The preservation of essential fatty acids can also be explained by the firmness of olives and the nonuse of alkaline treatment (Rallo et al., 2018; Jiménez et al., 1997).

\subsection{Antioxidant activity}

In this study, antioxidant activity was evaluated by two different chemical assays, the scavenging effect on DPPH free radicals and the reducing power (Figure 2 ). The raw fruit recorded high values for antioxidant scavenging activity (40654.13 $\mathrm{mg}$ GAE/ $/ \mathrm{kg}$ ) and reducing power (12296.79 $\mathrm{mg} \mathrm{QE} / \mathrm{kg}$ ). The inhibition rate of the DPPH radical and EC50 was $75.81 \%$ and $3.36 \mathrm{mg} / \mathrm{mL}$, respectively. The antioxidant activity
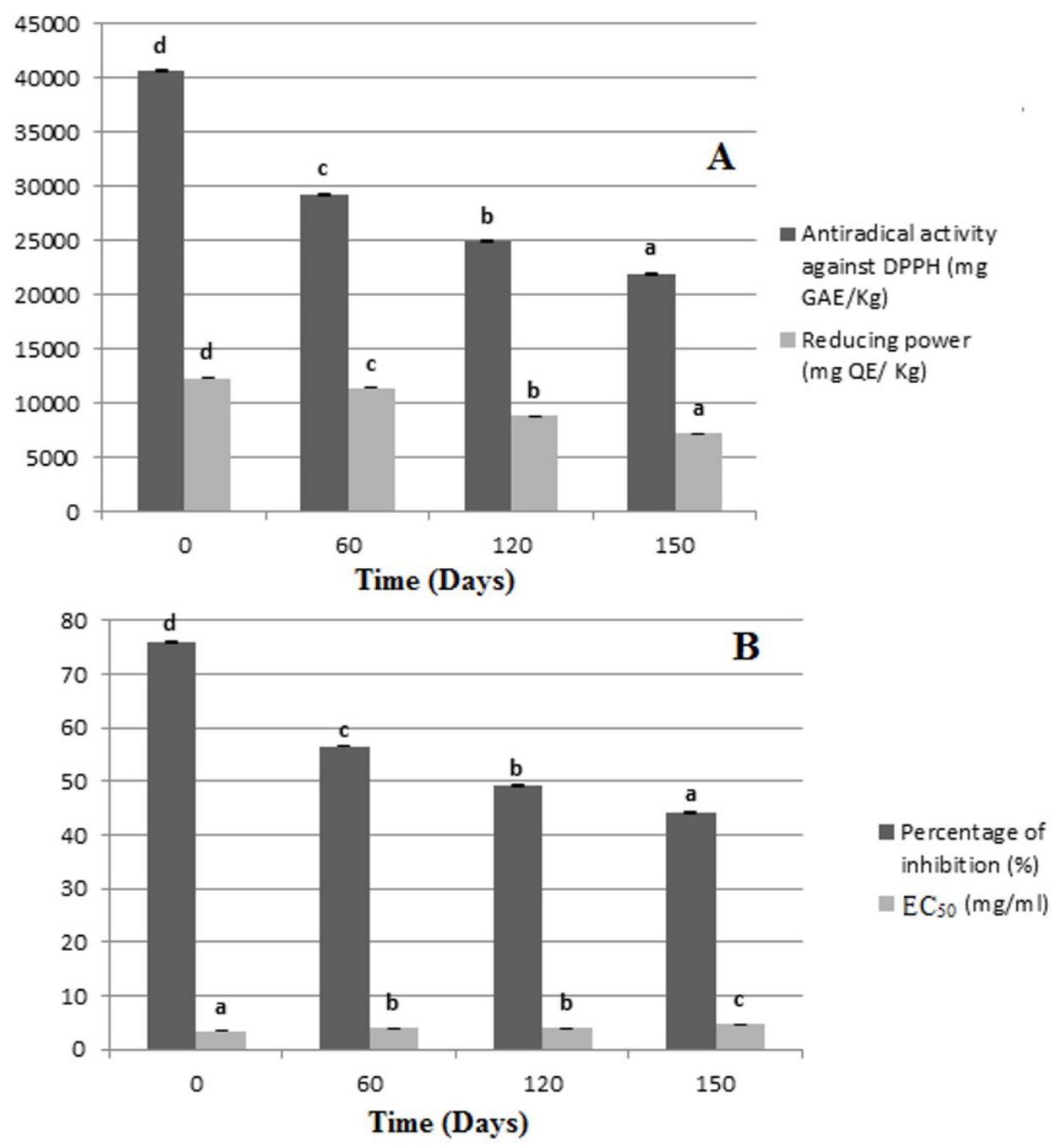

FIGURE 2. Antioxidant activity, reducing power (Panel A), percentage of inhibition and EC50 (Panel B) in turning color table olives of the Sigoise variety during natural-style processing. Results are given as mean of triplicate analyses. Significant differences are marked with different superscript letters using the Newman-Keuls test $(\mathrm{p}<0.05)$. Bars indicate standard deviation. GAE means gallic acid equivalents. QE means quercetin equivalents. 
decreased significantly throughout processing. The DPPH radical scavenging and reducing power decreased to $21917.71 \mathrm{mg}$ GAE $/ \mathrm{kg}$ and 7176.09 $\mathrm{mg} \mathrm{QE} / \mathrm{kg}$, respectively, with an inhibition rate of $44.20 \%$. The antioxidant activity showed a highly significant correlation with phenolic compounds $(r=0.99)$; whereas the effective concentration EC50 of the extracts was negatively correlated $(r=$ -0.91). According to several authors, there is a linear correlation between the total polyphenol content in table olives and their antioxidant activity (Ben Othman et al., 2009; Romero et al., 2004b; Sousa et al., 2014). Mettouchi et al. (2016) reported a similar behavior for the loss in reducing power but with the influence of environmental conditions for the same variety. Indeed, Sigoise from the Sig region exhibited a low reducing power compared to Sigoise from the Tazmalt region. The differences could be explained by the effectiveness of each phenolic component in the fruit composition. So far, the antioxidant activity depends on the concentration of the polyphenol profile. Furthermore, Ben Othman et al. (2009) monitored the evolution of phenolic compounds during the natural table olive elaboration of the Chétoui cultivar at three degrees of ripeness (green, turning color and black) and they found a decrease in the antioxidant activity by $60-72 \%$, with the turning color olives presenting an intermediate value. The Sigoise cultivar showed a lower reduction in the antioxidant capacity $(46.09 \%)$ due to a more moderate loss in phenolic compounds.

\section{CONCLUSIONS}

This study has characterized the main compounds, in particular, polyphenols, sugars, fatty acids and tocopherols, in the turning color table olives elaborated as natural-style of the Sigoise cultivar. The total polyphenol content decreased as the process progressed, except for the hydroxytyrosol, which increased at the beginning of brining and then decreased. There was also a consumption of sugars, especially glucose, which is typical of the fermentation process. The concentration of fatty acids was not affected by the elaboration process without significant differences throughout the process. The tocopherol concentration remained constant during the processing, and a decrease was only observed for $\alpha$-tocopherols after 150 days of brining. The losses in the latter and other phenolic compounds came as a consequent reduction in the antioxidant activity. Therefore, the turning color natural table olives of the Sigoise variety have an outstanding nutritional value and constitute an excellent source of antioxidant compounds that can exert beneficial properties to consumers.

\section{ACKNOWLEDGEMENTS}

We want to thank the Algerian Ministry of Higher Education and Scientific Research for sponsoring this work. The authors are grateful to the staff of the company KHODJA \& CO Seddouk (Bejaia, Algeria) for providing the samples. This work was also supported by the Spanish Government (Project RTI2018-093994-J-I00, AEI/FEDER, UE and Ramón y Cajal Programme RyC2018-024752-I).

\section{REFERENCES}

Ben Othman N, Roblain D, Chammen N, Thonart P, Hamdi M. 2009. Antioxidant phenolic compounds loss during the fermentation of Chétoui olives. Food Chem. 116, 662-669. https://doi.org/10.1016/j.foodchem.2009.02.084

Bleve G, Tufariello M, Durante M, Grieco F, Ramires FA, Mita G, Tasioula-Margari M, Logrieco AF. 2015. Physico-chemical characterization of natural fermentation process of Conservolea and Kalamata table olives and development of a protocol for the pre-selection of fermentation starters. Food Microbiol. 46, 368-382. https://doi. org/10.1016/j.fm.2014.08.021

Bonatsou S, Benitez A, Rodríguez-Gómez F, Panagou EZ, Arroyo-López FN. 2015. Selection of yeasts with multifunctional features for application as starters in natural black table olive processing. Food Microbiol. 46, 66-73. https:// doi.org/10.1016/j.fm.2014.07.011

Boskou D, Campasio S, Clodoveo ML. 2014. Table olives as source of bioactive compounds, in: Boskou D (Ed.) Olive and olive oil bioactive constituents, 1st edition. AOCS press, Urbana, IL, USA.

Boskou G, Salta FN, Chrysostomou S, Mylona A, Chiou A, Andrikopoulos NK. 2006. Antioxidant capacity and phenolic profile of table olives from the Greek market. Food Chem. 94, 558-564. https://doi.org/10.1016/j.foodchem.2004.12.005

European Commission regulation (ECC) No 2568/91 of July (1991) on the characteristics of olive oil and olive-residue oil and on the relevant methods of analysis, Official Journal of the European Communities 1991, OJ L 248, 5.9, 1-110. 
Commission Delegated Regulation (EU) 2016/2095 of 26 September 2016 amending Regulation (EEC) No 2568/91 of July (1991) on the characteristics of olive oil and olive-residue oil and on the relevant methods of analysis. Official Journal of the European Union 326/1-6.

Hassapidou MN, Balatsouras GD, Manoukas AG. 1994. Effect of processing upon the tocopherol and tocotrienol composition of table olives. Food Chem. 50, 111-114. https://doi.org/10.1016/03088146(94)90105-8

International Olive Oil Council (IOC). 2004. Trade Standard Applying to Table Olives, COI/OT/NC No. 1, Resolution No. RES-2/91-IV/04.

International Olive Oil Council (IOC). 2020. Updates Series of World Statistics on Production, Imports, Exports and Consumption. Internet: http://www. internationaloliveoil.org/estaticos/view/132world-table-olive-figures. Accessed 19 May 2020

Issaoui M, Dabbou S, Mechri B, Nakbi M, Chehab H, Hammami M. 2011. Fatty acid profile, sugar composition, and antioxidant compounds of table olives as affected by different treatments. Eur. J. Lipid Sci. Tech. 232, 867-876. https://doi. org/10.1007/s00217-011-1455-3

Jimenez A, Guillen R, Fernandez-Bolaños J, Heredia A. 1997. Factors Affecting the "Spanish Green Olive" Process: Their Influence on Final Texture and Industrial Losses. J. Agric. Food Chem. 45, 4065-4070. https://doi.org/10.1021/jf970161v

Johnson R, Melliou E, Zweigenbaum J, Mitchell AE. 2018. Quantitation of oleuropein and related phenolics in cured Spanish-style green, California-style black ripe and Greek-style natural fermentation olives. J. Agric. Food Chem. 66, 2121-2128. https://doi.org/10.1021/ acs.jafc. $7 \mathrm{~b} 06025$

Kacem M, Karam NE. 2006. Microbiological study of naturally fermented Algerian green olives: isolation and identification of lactic acid bacteria and yeasts along with the effects of brine solutions obtained at the end of olive fermentation on Lactobacillus plantarum growth. Grasas Aceites 57, 292-300. https://doi.org/10.3989/gya.2006.v57.i3.51

Kiai H, Hafidi A. 2014. Chemical composition changes in four green olive cultivars during spontaneous fermentation. LWT - Food Sci. Technol. 57, 663-670. https://doi.org/10.1016/j. lwt.2014.02.011
McDonald S, Prenzler PD, Antolovich M, Robards K. 2001. Phenolic content and antioxidant activity of olive extracts. Food Chem. 73, 73-87. https://doi.org/10.1016/S0308-8146(00)00288-0

Marsilio V, Campestre C, Lanza B, DeAngelis M. 2001. Sugar and polyol compositions of some European olive fruit varieties (Olea europaea L.) suitable for table olive purposes. Food Chem 72, 485-490. https://doi.org/10.1016/S0308-8146(00)00268-5

Medina E, Brenes M, Romero C, Garcia A, Castro A. 2007. Main antimicrobial compounds in table olives. J. Agr. Food Chem. 55, 9817-9823. https:// doi.org/10.1021/jf0719757

Medina E, Gori C, Servili M, de Castro A, Romero C, Brenes M. 2010. Main variables affecting the lactic acid fermentation of table olives. Int. J. Food Sci. Tech. 45, 1291-1296. https://doi. org/10.1111/j.1365-2621.2010.02274.x

Medina E, Romero C, Brenes M, García P, de Castro A, García A. 2008. Profile of anti-lactic acid bacteria compounds during the storage of olives which are not treated with alkali. Eur. J. Lipid Sci. Tech. 228, 133-138. https://doi.org/10.1007/ s00217-008-0916-9

Mettouchi S, Bachir Bey M, Tamendjari A, Louaileche H. 2016. Antioxidant activity of table olives as influenced by processing method. International Journal of Chemical and Biomolecular Science 2, 8-14. http://www.aiscience.org/journal/ijcbs

Poiana M, Romeo FV. 2006. Changes in chemical and microbiological parameters of some varieties of Sicily olives during natural fermentation. Grasas Aceites 57, 402-408. https://doi.org/10.3989/ gya.2006.v57.i4.66

Ramírez E, Brenes M, de Castro A, Romero C, Medina E. 2017. Oleuropein hydrolysis by lactic acid bacteria in natural green olives. $L W T$ - Food Sci. Technol. 78, 165-171. https://doi. org/10.1016/j.lwt.2016.12.040

Ramirez E, Brenes M, Garcia P, Medina E, Romero C. 2016. Oleuropein hydrolysis in natural green olives: importance of endogenous enzymes. Food Chem. 206, 204-209. https://doi.org/10.1016/j. foodchem.2016.03.061

Rallo P, Morales Sillero A, Brenes M, Jimenez MR, Sanchez AH, Suarez MP, Casanova L, Romero C. 2018. Elaboration of table olives: assessment of new olive genotypes. Eur. J. Lipid Sci. Tech. 120, 1800008. https://doi.org/10.1002/ejlt.201800008 
Romero C, Brenes M, Garcia P, Garcia A, Garrido A. 2004a. Polyphenol changes during fermentation of naturally black olives. J. Agr. Food Chem. 52, 1973-1979. https://doi.org/10.1021/jf030726p

Romero C, Brenes M, Garcia P, Garcia A, Garrido, A. 2004b. Effect of cultivar and processing method on the contents of polyphenols in table olives. J. Agr. Food Chem. 52, 479-484. https:// doi.org/10.1021/jf0305251

Rovellini P, Azzolini M, Cortesi N. 1997. Tocoferoli e tocotrienoli in oli e grassi vegetali. Riv. Ital. Sostanze Gr. 74, 1-5.

Sagratini G, Allegrini M, Caprioli G, Cristalli G, Giardina D, Maggi F. 2013. Simultaneous determination of squalene, $\alpha$-tocopherol and $\beta$-carotene in table olives by solid phase extraction and high performance liquid chromatography with diode array detection. Food Anal. Methods 6, 5-60. https://doi.org/10.1007/s12161-012$9422-6$

Sakouhi F, Harrabi S, Absalon C, Sbei K, Boukhchina S, Kallel H. 2008. $\alpha$-Tocopherol and fatty acids contents of some Tunisian table olives (Olea europea L.): Changes in their composition during ripening and processing. Food Chem. 108, 833-839. https://doi.org/10.1016/j.foodchem.2007.11.043

Sousa A, Malheiro R, Casal S, Bento A, Pereira JA. 2014. Antioxidant activity and phenolic composition of $\mathrm{Cv}$. Cobrançosa olives affected through the maturation process. J. Funct. Foods 11, 20-29. https://doi.org/10.1016/j. jff.2014.08.024

Susamci E, Romero C, Tuncay O, Brenes M. 2017. An explanation for the natural debittering of Hurma olives during ripenning on the tree. Grasas Aceites 68, 182-189. https://doi.org/10.3989/ gya.1161162

Tovar MJ, Romero M P, Girona J, Motilva MJ. 2002. L-Phenylalanine ammonia-lyase activity and concentration of phenolics in developing olive (Olea europaea L cv Arbequina) fruit grown under different irrigation regimes. J. Sci. Food Agric. 82, 892-898. https://doi.org/10.1002/jsfa.1122

Zhan Y, Hong-Dong C, Yao YJ. 2006. Antioxidant activities of aqueous extract from cultivated fruitbodies of Cordyceps militaris (L.) Link in vitro. J. Integr. Plant Biol. 48, 1365-1370. https://doi. org/10.1111/j.1744-7909.2006.00345.x 